BOGNA RUTKOWSKA

Instytut Etnologii i Antropologii Kulturowej UW, Warszawa

\title{
ZAMIESZKUJACC „POGRANICZE”. MIGRACJA PRZYGRANICZNA Z POLSKI DO NIEMIEC W DOŚWIADCZENIACH DZIECI I RODZICÓW
}

Od ponad dekady we wschodniej części Meklemburgii-Pomorza Przedniego i północno-wschodniej Brandenburgii rozwija się zjawisko migracji transgranicznej Polaków do niemieckich wsi. Obecnie w niektórych z nich Polacy stanowią prawie połowę mieszkańców. Podczas badań prowadzonych w przygranicznych wsiach ${ }^{1}$ interesowały mnie początkowo motywacje moich rozmówców do przeprowadzki oraz ich doświadczenie funkcjonowania w nowej sytuacji. Choć w większości rodzin trwa pamięć o migracjach przodków (jest wśród nich wielu potomków przesiedleńców ze wschodniej części przedwojennej Polski), dla przeprowadzających się Polaków jest to często pierwsze doświadczenie związane z przeprowadzką za granicę. Jednakże wielu z moich rozmówców nie traktuje własnego doświadczenia jako emigracji, zachowując wiele połączeń z polską stroną i mając możliwość codziennego przekraczania granicy.

Podczas gdy dla rodziców pojęcie pogranicza jest znaczącą kategorią, dla doświadczenia dzieci bliskość granicy ma mniejsze znaczenie, a ich sytuację trafniej można opisać w języku badań nad migracją dzieci i migracją transnarodową ${ }^{2}$. Co ciekawe, rodzice także traktują doświadczenie swoich dzieci w odmienny sposób niż własne. Zdaniem rodziców przeprowadzka dzieci do Niemiec ma być dla tych ostatnich

${ }^{1}$ Niniejszy artykuł powstał na podstawie badań przeprowadzonych w ramach laboratorium etnograficznego „Życie na granicy - transgraniczne praktyki mieszkańców polsko-niemieckiego przygranicza" realizowanego pod kierunkiem dr hab. Agnieszki Halemby w latach 2016-2018 w Instytucie Etnologii i Antropologii Kulturowej UW. Analizowany materiał stanowią przede wszystkim rozmowy i wywiady z polskimi mieszkańcami niemieckiej wsi Nadrensee oraz okolicznych miejscowości, chociaż podczas badań wiele wywiadów przeprowadziłam także po polskiej stronie granicy. Rozmawiałam przede wszystkim z nauczycielami, rodzicami i dziećmi. W przypadku migrantów prawie zawsze były to osoby, które zamieszkały w Niemczech w ostatniej dekadzie. Z nastolatkami i z dorosłymi przeprowadzałam wywiady, często miałam także okazję porozmawiać z młodszymi dziećmi - gdy dosiadały się podczas wywiadu $\mathrm{z}$ ich rodzicami lub w czasie wspólnych podwórkowych zabaw. Wśród mieszkańców Nadrensee przeprowadziłam również ankietę przygotowaną przez Agnieszkę Misiuk, Agnieszkę Halembę oraz Otto Habecka. Ankiety te były najczęściej wstępem do bardziej pogłębionych wywiadów, które następnie transkrybowałam i analizowałam. W sumie przeprowadziłam około 60 wywiadów (w tym 15 z nastolatkami) oraz wiele luźnych rozmów.

${ }^{2}$ Wszystkie rozmowy z dziećmi przeprowadziłam za zgodą lub w obecności rodziców i z uszanowaniem założeń etyki badań z udziałem dzieci (zob. np. Powell i in. 2013). 
doświadczeniem formatywnym, zmieniającym to, w jaki sposób postrzegają siebie, Polskę, Niemcy, a przede wszystkim swoją przyszłość. Z punktu widzenia rodziców przeprowadzka jest inwestycją w przyszłość dzieci, ze szczególnym uwzględnieniem zapewnienia im kapitału kulturowego w postaci dwujęzyczności. Jednak perspektywa dzieci różni się często od narracji rodziców. Nie oceniają one swojej sytuacji przez pryzmat tego, co przeprowadzka może dać im w przyszłości. O wiele bardziej zanurzone w czasie teraźniejszym, doświadczają dużej życiowej zmiany. Moim celem jest analiza perspektywy zarówno dzieci, jak i rodziców, co pozwoli także na krytyczne przyjrzenie się pewnym tezom dotyczącym terenów przygranicznych.

\section{POGRANICZE CZY PRZYGRANICZE}

Michał Buchowski (2011) zauważa, że z punktu widzenia ludzi mieszkających w pobliżu granic państwowych teren ten jest miejscem jak każde inne, a relacje społeczne na pograniczu nie muszą odznaczać się niczym nadzwyczajnym. Mimo to proponuje on rozumienie pogranicza jako strefy zawierającej także „długotrwałe zjawiska kulturowe charakterystyczne dla tego typu sfer jak np. dwujęzyczność, przenikanie się kultur, [...] przejmowanie obyczajów" (tamże, s. 9). Według autora istnieją pewne cechy i uwarunkowania, które są dla terenów przygranicznych szczególne. Wyniki badań Buchowskiego, prowadzonych koło Frankfurtu nad Odrą i Słubic, pokazują, że na pograniczu granica się zaciera, przestrzeń kulturowa zagęszcza i zapełnia, a ludzie tworzą powoli swoją lokalną ojczyznę, w której można przekroczyć etniczne i historyczne podziały. Autor interpretuje to jako proces tworzenia się pogranicza.

Podobnie pisze o pograniczu polsko-niemieckim Paweł Ładykowski, który w latach 2008-2011 wraz z Łukaszem Kaczmarkiem oraz studentami etnologii w Szczecinie prowadzil, na tym samym co ja terenie, badania w ramach laboratorium Portret etnograficzny rodzacego się polsko-niemieckiego pogranicza. Ładykowski (2011) traktuje pogranicze jako space-in-between, przestrzeń liminalną, w której ścierają się ze sobą zwyczaje, sposoby życia i języki. Według niego zjawisko zasiedlania niemieckich wsi przez Polaków to proces tworzenia się pogranicza i zarazem nowych relacji na linii państwo-obywatel oraz relacji społecznych pomiędzy Polakami i Niemcami, powstaje tam nowa „formuła pogranicza” (tamże, s.44). Ładykowski pojmuje je jako „zjawisko, które wprawdzie przejawia się w lokalnym życiu codziennym, ale ma szansę w perspektywie nadchodzącej dekady dokonać wielu istotnych przemian na skalę europejską, opowiada nam bowiem o skutkach zniesienia przejawów granic państwowych" (tamże, s. 48). Pisząc o nowych polskich mieszkańcach niemieckich wsi, podkreśla istnienie tzw. liderów lokalnej tożsamości, ludzi zaangażowanych w oddolne jej tworzenie, gdyż, jak zauważa, na razie trudno nazwać ten teren pograniczem - dopiero zaczyna się ono rodzić.

Jednak w Nadrensee, w którym prowadziłam większość badań będących materiałem do niniejszego artykułu, nie ujawnił się żaden „lider”, a mieszkańcy raczej nie angażują się w odgórnie organizowane działania integrujące. Taka sytuacja jest 
często diagnozowana przez różnego rodzaju zewnętrzne organizacje mające wspierać rozwój pogranicza jako nieodpowiednia i niepożądana. Między innymi z tego powodu powstał projekt Perspektywy organizacji RAA ${ }^{3}$, do którego realizacji zostałam zaproszona wraz ze Stanisławem Mazurkiem i Isabel Cellati. Naszym zadaniem było przeprowadzenie ankiety wśród mieszkańców Nadrensee, aby organizatorzy projektu mogli lepiej ocenić sytuację i dostosować do niej swoje działania na rzecz integracji polsko-niemieckiej. Co jednak istotne, okazało się, że niektóre z pytań w ankiecie skrywały w sobie pewne przedsądy, założenia, które uświadomili nam rozmówcy - zaskoczone lub ironiczne komentarze ujawniały ich stosunek do tematów, które następnie mogłam rozwijać $w$ wywiadach pogłębionych. Na przykład mówili do nas: „Po co tyle pytań o relacje sąsiedzkie i ich poprawę, nie trzeba się przecież z każdym przyjaźnić!”, albo: „Wieś? Gdzie to jest wieś?” Komentarze do ankiety były o wiele bardziej pomocne niż same odpowiedzi na pytania.

Podczas przeprowadzania ankiety oraz długich rozmów i wywiadów z mieszkańcami stało się dla nas jasne, że postrzegają oni swoją sytuację inaczej niż działacze na rzecz tworzenia pogranicza. Mają odmienny stosunek zarówno do miejsca, jak i samej idei wspólnego zamieszkiwania (na którą takie organizacje kładą nacisk), ponieważ nie są nastawieni na współtworzenie nowej lokalnej, zintegrowanej społeczności, lecz mają zupełnie inne cele. Jak pisze Agnieszka Halemba, „codzienne relacje mieszkańców regionu po obu stronach granicy państwowej są oparte raczej na celach pragmatycznych, bliskich poszczególnym jednostkom" (2017, s. 18). Również Peggy Levitt (2001) zauważa, że wiele badań naukowych skupia się na transnarodowych relacjach między mieszkańcami, co nie pozwala zauważyć wielowymiarowości zjawiska transnarodowych praktyk i relacji społecznych. Według autorki należy patrzeć na doświadczenie migrantów przez pryzmat transnarodowego pola społecznego rozumianego jako:

Zbiór wielu powiązanych ze sobą sieci relacji społecznych, za pomocą których idee, praktyki i zasoby są nierównomiernie wymieniane, organizowane i przekształcane. [...] Granice państwowe niekoniecznie przylegają do granic pól społecznych. Narodowe pola społeczne to takie, które pozostają w granicach państwowych, podczas gdy ponadnarodowe pola społeczne łączą podmioty poprzez bezpośrednie i pośrednie relacje ponad granicami (Levitt 2001, s. 2).

Dzięki takiemu spojrzeniu nie koncentrujemy się na „asymilacji” bądź jej braku, co autorka nazywa „metodologicznym nacjonalizmem” (Levitt, Glick Schiller 2004), możemy natomiast zauważyć, w jaki sposób jednostki konstruują granice swojego pola społecznego. W przypadku rodziców, z którymi rozmawiałam, granica państwowa ma duże znaczenie, chcę jednak położyć nacisk na to, iż jednostki w aktywny sposób wykorzystują ją do rozmaitych własnych celów. Ich doświadczenie to specyficzny przykład migracji transgranicznej, ponieważ w tym przypadku zjawisko migracji zachodzi w niewielkiej odległości od granicy państwowej. Jest to szczególna forma transnacjonalizmu, który w swojej najbardziej ogólnej definicji odnosi się do kulturowych, ekonomicznych i politycznych ponadnarodowych połączeń ludzi

${ }^{3}$ https://www.perspektywa.de/, dostęp 06.12.2018. 
i instytucji w zróżnicowanych kontekstach (Sørensen 2000). Przedmiot moich badań dotyczy poszczególnych, pragmatycznych i osobistych celów transgranicznych migracji oraz tego, jak wpływa na nią geograficzna bliskość granicy państwowej.

Zdecydowałam się używać terminu "przygranicze” zaproponowanego przez Andrzeja Sadowskiego (2004), ponieważ to właśnie obecność granicy państwowej wpływa na decyzje moich dorosłych rozmówców i charakter ich migracji. Zjawiska charakterystyczne dla pogranicza, takie jak te opisane przez Buchowskiego (przenikanie się kultur, dwujęzyczność, przejmowanie obyczajów) należą raczej do postulatów liderów różnego rodzaju organizacji pozarządowych, rządowych i europejskich niż do codziennych doświadczeń moich rozmówców. To granica, konstruowana przez ludzi w codziennych działaniach, a także mogąca stać się dla nich zasobem, w dużym stopniu moderuje dynamikę społeczną w tym regionie.

Zgodnie z tym, co pisali Michał Buchowski (2011) i Agnieszka Pasieka (2016), wychodzę z założenia, że aby zrozumieć, jakie znaczenie ma granica dla zamieszkujących dany teren ludzi, należy przyjrzeć się ich praktykom i zrozumieć ich interpretacje własnego doświadczenia, ich potrzeby, działania, wartości. Przygranicze traktuję jako miejsce umożliwiające pewne wybrane praktyki i taktyki, ale przede wszystkim interesuje mnie, w jaki sposób interpretuje się ją jako szansę na lepszą przyszłość, zwłaszcza dla dzieci.

\section{MIGRACJA PRZYGRANICZNA NA POMORZU PRZEDNIM I W PÓŁNOCNEJ BRANDENBURGII}

Przeprowadzki Polaków do niemieckich wsi przygranicznych to zjawisko stosunkowo nowe. Co prawda podczas badań spotkałam też Polaków mieszkających w Niemczech już od ponad 30 lat, jednakże były to pojedyncze, wyjątkowe przypadki. Ich sytuacja w momencie przeprowadzki była też inna - przeprowadzali się bowiem za granicę, której nie można było przekraczać tak łatwo, jak obecnie. Można powiedzieć, że ich przeprowadzka była decyzją o emigracji, o przeniesieniu całego swojego życia na drugą stronę granicy. Kiedy Polska dołączyła do UE w 2004 roku, Polacy pracujący w Niemczech otrzymali możliwość mieszkania tam bez konieczności wyrabiania wizy. Polska emigracja do Niemiec stawała się coraz łatwiejsza wraz z wejściem Polski do strefy Schengen w 2007 roku i pełną liberalizacją niemieckiego rynku pracy w 2011 roku (Łada i Segeš Frelak 2012, s. 7). W tym czasie rozpoczęła się przygraniczna migracja na większą skalę - Polacy, głównie szczecinianie, zaczęli kupować domy w opustoszałych wsiach przygranicznych byłego NRD, regionu słabo rozwiniętego ekonomicznie, o sporej stopie bezrobocia i nasilonej obecności skrajnej prawicy w polityce lokalnej. Był to region, z którego wielu mieszkańców, głównie młodych i wykwalifikowanych, wyjechało już w latach 90. (Balogh 2013). Sprowadzający się Polacy to głównie młodzi rodzice, w większości wykształceni i z aspiracjami edukacyjnymi dla swoich dzieci. Obecnie w niektórych przygranicznych wsiach większość mieszkańców przed pięćdziesiątym rokiem życia stanowią Polacy. 
Bezpośrednim impulsem do decyzji o przeprowadzce była dla wielu osób różnica cen nieruchomości po obu stronach granicy. Po niemieckiej stronie wiele domów stało pustych, a szkoły i przedszkola zamykano - brakowało zarówno dzieci, jak i wykwalifikowanych nauczycieli. W związku z tym ceny domów spadały, podczas gdy w Szczecinie i okolicach drastycznie wzrastały. Wiele osób decydowało się więc na taką transgraniczną przeprowadzkę. W wyniku tych decyzji pojawiały się w niemieckich wsiach polskie dzieci i młodzież, zaczęto więc ponownie otwierać szkoły i przedszkola, w których coraz częściej zatrudnienie znajdowali również polscy nauczyciele. Dziś funkcjonuje także polsko-niemieckie gimnazjum w Loecknitz, w regionie wiele jest wydarzeń i aktywności organizowanych przez lokalne organizacje działające na rzecz integracji mieszkańców czy zapewniające pomoc przy formalnościach związanych z przeprowadzką. Większość moich rozmówców przeniosła jednak do Niemiec tylko pewne aspekty życia: mieszkanie i edukację dzieci. W Polsce mają zaś większość przyjaciół i znajomych, robią tam zakupy, często także kontynuują pracę. Bliskość granicy, a w wielu przypadkach także bliskość dawnego miejsca zamieszkania, pozwala na zachowanie połączeń z Polską i życiem sprzed przeprowadzki.

Specyficzna historia terenu, ale także jego przyroda, infrastruktura i przebieg granicy mają wpływ na zaistnienie oraz charakter zjawiska migracji przygranicznej. W miejscu, w którym prowadziłam badania, granica oddala się od Odry, co stwarza mieszkańcom wiele możliwości szybkich dojazdów do i ze Szczecina lub Gryfina.

Nadrensee, które stało się głównym miejscem moich badań, ma tylko 273 mieszkańców, z tego 125 deklaruje się jako Polacy ${ }^{4}$. Główna ulica wsi jest przeważnie pusta, z wyjątkiem dwóch momentów podczas dnia, kiedy dzieci i młodzież idą do lub wracają ze szkoły, do której zawozi je szkolny autobus. Na jednym z końców wsi można skręcić w Sportstrasse (ulicę Sportową), wzdłuż której stoi rząd kilku niskich bloków. Zbudowane były dla celników, którzy w większości opuścili miejscowość po otwarciu granicy, a dziś niemal w całości zamieszkane są przez Polaków. To małe osiedle, sprawiające wrażenie odrębnej części wsi, jest jedynym miejscem, w którym można liczyć na spontaniczne spotkanie z mieszkańcami, zwłaszcza latem, kiedy pod blokami bawi się gromadka polskich dzieci. Stosunkowo łatwo jest także spotkać ich rodziców, którzy kursują między domem, szkołami i przedszkolami, zakupami w Szczecinie i urzędami w Loecknitz czy Penkun, a czasem wychodzą przed blok zapalić papierosa.

We wsi mieści się także przedszkole i kościół ewangelicki, w którym nabożeństwa odbywają się tylko kilka razy w roku. Na drugim końcu Dorfstrasse (ulicy Wiejskiej) znajduje się jezioro i niewielkie, skromnie urządzone miejsce biwakowe. Spośród wszystkich miejscowości przygranicznych, które odwiedziłam po niemieckiej stronie, Nadrensee jestem najbardziej skłonna nazwać wsią - jest to mała miejscowość ze wszystkich stron otoczona zielenią. Jednak nie wszyscy mieszkańcy Nadrensee, z którymi rozmawiałam, uważają miejsce swojego zamieszkania za wieś. Wiąże się to $\mathrm{z}$ trybem ich życia i pozostaniem w bliskich związkach z Polską, a zwłaszcza

${ }^{4}$ Informacja pochodzi od pani sołtys. W Pomellen, należącym do tej samej gminy, na 98 mieszkańców 61 to Polacy. 
Szczecinem - często traktują oni Nadrensee jak jego przedmieścia. Ich definicja tego miejsca zależy w dużej mierze od motywacji do przeprowadzki, trybu życia oraz oczekiwań związanych z mieszkaniem w przygranicznej miejscowości w Niemczech. Z rozmów, które przeprowadziłam, wynika, że często celem przeprowadzki jest inwestycja w przyszłość dzieci poprzez zapewnienie im dwujęzyczności.

\section{RODZICE}

Jak piszą Melanie Griffiths, Ali Rogers i Bridget Anderson (2013, s. 6), migracja może być przeżywana lub przewidywana jako specyficzny okres wyłączony (time out) z reszty życia. Można ją również postrzegać jako „budulec” (building block) tego życia, przynoszący konkretne doświadczenia, kontakty, umiejętności, które mogą okazać się ważne w przyszłości - jako zbieranie różnych rodzajów kapitału kulturowego i społecznego. Odnosząc te obserwacje do terenu moich badań, można zauważyć, że migracja Polaków do niemieckich wsi jest pewnego rodzaju inwestycją na przyszłość. Kategoria migracji jako budulca czy sposobu gromadzenia kapitału dotyczy tu przede wszystkim przyszłości dzieci.

Korzyści, jakie przeprowadzka miała przynieść rodzicom, były głównie materialne - większe mieszkanie lub dom, mniejsze koszty jego utrzymania, wiejski krajobraz. Odmienne postrzeganie sytuacji swojej i dzieci ma, jak się wydaje, duży związek z bliskością granicy (Junxi Qian, Hong Zhu, Yi Liu 2011). Osoby, z którymi rozmawiałam, opowiadały, że przy podejmowaniu decyzji przekonywały same siebie, że to przecież bardzo blisko i że właściwie nic się nie zmieni. Mieszkanie blisko granicy z Polską umożliwia Polakom zachowanie wielu elementów życia sprzed przeprowadzki (praca, znajomi, zakupy). Stwarzają w ten sposób rodzaj transnarodowego pola społecznego (Basch, Glick Schiller, Szanton Blanc 1995; Levitt 2001). Często większość ich życia koncentruje się po polskiej stronie, choć mieszkają w Niemczech i tam posyłają dzieci do szkoły. Dorośli migranci mogą traktować niemieckie wsie jak przedmieścia Szczecina. Podkreślają, że jadą tam zaledwie 20 minut samochodem, robią tańsze, lepsze zakupy, nie stanowi dla nich problemu zostawienie dziecka u dziadków i pójście na imprezę. Dzięki bliskości granicy moi rozmówcy mogą pozostać w kontakcie ze światem, który znają i który jest im bliski. Co więcej, wielu z nich w innej sytuacji w ogóle nie zdecydowałoby się na przeprowadzkę. Życie przy granicy pozwala czerpać korzyści po obu jej stronach, zarazem unikając negatywnych aspektów emigracji, takich jak odcięcie od rodziny i znajomych czy zbyt drogie koszty życia w zachodnich regionach Niemiec. Możliwość takiego lawirowania czy wręcz wrażenie pozostania w Polsce często jest powodem, dla którego moi rozmówcy nie zastanawiają się długo nad decyzją o przeprowadzce.

Choć można by się spodziewać, że język wyraźnie zaznacza granice państwowe, nawet on nie zawsze jest przeszkodą dla mieszkańców Nadrensee. Często dorośli migranci nie mają potrzeby lub czasu na zawieranie znajomości z nowymi sąsiadami (lub zawierają je tylko z Polakami), a w urzędach można porozumieć się po polsku, 
ewentualnie łamanym niemieckim. Inna z moich rozmówczyń, Iza, zna niemiecki na tyle, by załatwić sprawy w urzędach i choć zauważa, że jej córka mówi znacznie lepiej od niej, nie sądzi, by znajomość języka na wyższym poziomie była jej samej potrzebna. Rozmawiałam z nią, kiedy była na urlopie macierzyńskim i jeszcze nie zdecydowała, czy po porodzie wróci do pracy w Polsce, czy pozostanie na (niemieckim) bezrobociu. Mąż Izy ma dobrze płatną posadę w Szczecinie i nie opłaca mu się szukać pracy w Niemczech, dlatego na razie zachowują taki tryb życia - z pracą w Polsce i domem w Niemczech.

Taki sposób życia można interpretować zgodnie z pojęciem granicy przedstawionym przez Sarah Green (2017). Dla moich rozmówców granica nie znajduje się tam, gdzie są ustawione polskie i niemieckie słupy graniczne. Bliskość granicy pozwala na indywidualne, sprawcze jej „zaznaczanie”. Można powiedzieć, że sami decydują, które ślady (traces) reżimów państwowych mają znaczenie w ich codziennym życiu, a które chcą - i potrafią - ignorować. Ze względu na wagę, jaką przywiązują do dwujęzycznego wychowania dzieci, można uznać, że zamieszkują po niemieckiej stronie granicy, jeśli przyjąć jako odniesienie system szkolnictwa; natomiast jeśli chodzi o relacje przyjacielskie i rodzinne, pozostali w Polsce. Granica jest dla nich nie tyle linią rozdzielająca dwa kraje, ile potencjałem, zasobem, który można wykorzystywać zależnie od własnych potrzeb, tworząc w ten sposób transnarodową przestrzeń pola społecznego (Levitt 2001; Ślusarczyk, Pustułka 2017, s.23, 24). Według dorosłych migrantów do Niemiec można przeprowadzić się tylko w wybranych wymiarach życia - w takim ujęciu granica staje się tidemark, znakiem na piasku, którego zasięg zmienia się zależnie od tego, z jakiego punktu widzenia i w którym momencie na niego spojrzymy, i który może znów się zmienić (por. Halemba 2017).

Inaczej jednak rodzice postrzegają przeprowadzkę swoich dzieci. Obok pragmatycznych kalkulacji, o których była mowa wyżej, troska o przyszłość dzieci często występuje w ich wypowiedziach jako motywacja do przeprowadzki. Samo doświadczenie migracji dzieci często jest przez dorosłych opisywane w kategoriach przyszłości, a skala zmian często jest w ich mniemaniu większa niż rodziców (Junxi Qian, Hong Zhu, Yi Liu 2011).

Według moich rozmówców państwo niemieckie zapewnia dzieciom wsparcie i opiekę już teraz (Kindergeld, darmowe leczenie i przybory szkolne), ale przede wszystkim lepsze szanse na przyszłość. Przeprowadzka ma na celu zapewnienie im w późniejszym życiu większych szans zatrudnienia i lepszej sytuacji finansowej. Posłanie dzieci do niemieckich instytucji oświatowych jest więc traktowane jako inwestycja w ich przyszłość. System szkolnictwa w Brandenburgii i Meklemburgii-Pomorzu Przednim składa się ze szkoły podstawowej, po której można pójść do szkoły zawodowej lub kontynuować naukę w gimnazjum, tj. w szkole, która kończy się maturą i umożliwia studia. Uczniowie są także zobligowani do odbycia praktyk zawodowych, a państwo oferuje im dodatkowo liczne nieodpłatne kursy, które pozwalają na zdobywanie poszukiwanych zawodów lub kompetencji w takich zawodach przydatnych. Rodzice sądzą, że dzięki takiej strukturze szkolnictwa ich dzieci nie będą miały problemów ze znalezieniem pracy. Jednak najważniejsza wydaje się im 
możliwość perfekcyjnego nauczenia się przez dzieci drugiego języka. Panuje przekonanie, że dwujęzyczność to nie tylko rozwój osobisty, lecz przede wszystkim pewność znalezienia dobrze płatnego zajęcia i większe możliwości wyboru drogi życiowej.

Rodzicom tak bardzo zależy na zapewnieniu dzieciom kapitału na przyszłość, że często bagatelizują trudności, których dzieci doświadczają w związku z funkcjonowaniem w nowej rzeczywistości, w ten sposób utwierdzając się w przekonaniu, że decyzja o przeprowadzce była słuszna. Choć wielu rodziców zachowuje bliski kontakt z Polską, po przeprowadzce często niemal nie zmieniając dawnego trybu życia, pracy i kręgu znajomych i nie nawiązując wielu kontaktów z niemieckimi sąsiadami, od dzieci oczekują pełnego zanurzenia w nowej rzeczywistości, przynajmniej jeśli chodzi o szkołę. Zdaniem rodziców dla dzieci kontakty polsko-niemieckie są zwyczajną codziennością i to one tworzą wielokulturowe pogranicze - marzenie wielu aktywistów społecznych i politycznych w tym regionie (Halemba 2017; Pasieka 2016; Zarycki 2011a, 2011b). $\mathrm{W}$ takim rozumieniu granica miałaby nie mieć dla dzieci żadnego znaczenia. Michał Buchowski (2011) zauważył, że z punktu widzenia mieszkańców pogranicze jest podobne do każdego innego obszaru, jakkolwiek arbitralnie wyznaczonego. W wypowiedziach moich rozmówców widać jednak, że takie spojrzenie na obszar przygraniczny jest charakterystyczne dla pokolenia rodziców patrzących na swoje dzieci; nie jest ich zdaniem odpowiednie do opisania ich własnej sytuacji. Rodzice bowiem uważają, że dzieci (zwłaszcza te młodsze) nie muszą interpretować miejsca, w którym się wychowują, poprzez obecność granicy, mogą nie odczuwać jej w codziennym życiu. To, co dorośli postrzegają jako transgraniczność czy pograniczność, dla dzieci ma być jedną przestrzenią, w której ślady (traces) granicy nie mają znaczenia (Green 2017).

Dzieci miałyby w tej perspektywie „naturalnie” chłonąć język niemiecki i integrować się z niemieckimi rówieśnikami. Dorośli twierdzą, że relacje polsko-niemieckie wśród osób starszych zazwyczaj nie są zażyłe; często są nawet postrzegane jako niepotrzebne czy kłopotliwe. Jest wiele przyczyn tej sytuacji, m.in. różne języki, brak czasu, inny tryb życia i różnica wieku polskich i niemieckich mieszkańców. Z punktu widzenia większości moich rozmówców relacje z niemieckimi sąsiadami „są, jakie są” i nie widzą oni potrzeby nadmiernej „integracji”. Z kolei przez organizacje lokalne diagnozowane są one jako wymagające poprawy i są przedmiotem różnorakich projektów integracyjnych. Jednak, co ciekawe, temat relacji polsko-niemieckich wśród dzieci nie jest tak często podejmowany w dyskusjach nad „problemem integracji”. Choć wiele projektów jest kierowanych także do dzieci i młodzieży, nie spotkałam się z diagnozowaniem relacji polsko-niemieckich między dziećmi mieszkającymi w jednej miejscowości jako problematycznych ${ }^{5}$. Przyjmuje się, że wśród dzieci integracja następuje o wiele szybciej i łatwiej lub wręcz sama z siebie, jedynie w wyniku codziennego kontaktu, natomiast jako problem postrzegana jest integracja średniego i starszego pokolenia.

${ }^{5}$ Istnieją organizacje mające na celu zbliżenie młodych Polaków i Niemców, np. „Deutch-Polnisches Jugendwerk Polsko-Niemiecka Współpraca Młodzieży”, pod linkiem: http://www.pnwm.org/, dostęp 15.06.2018. 
Rodzice, a także ich dzieci, podkreślają, że niemiecki język, system szkolnictwa, koleżanki i koledzy, stają się dzieciom bliższe niż związki z Polską (oparte zazwyczaj na kontaktach z dziadkami, zajęciach dodatkowych w Szczecinie, zakupach). Dzieci coraz bardziej zrastają się ze swoim niemieckim otoczeniem społecznym i ich ścieżki prowadzą w stronę Niemiec. Niekiedy jest to nawet powodem do rozważania przez rodziców przeprowadzki w głąb kraju. Niezależnie od dalszych planów rodziców (niektórzy spośród moich rozmówców w Nadrensee rozważają również powrót do Polski), widzą oni przyszłość młodszego pokolenia „tu”, czyli w Niemczech. Nie dotyczy to konkretnie zamieszkiwanego przez nich obecnie regionu - spodziewają się raczej, że ich dzieci wyjadą do jednego z większych miast niemieckich i mają nadzieję, że znajdą dobrze płatną pracę $\mathrm{w}$ regionie lepiej rozwiniętym ekonomiczne.

\section{DZIECI}

Dla rodziców bliskość granicy i łatwość jej przekraczania często odgrywają ważną rolę - skłaniają ich do podjęcia decyzji o przeprowadzce, pozwalają pozostać „jedną nogą" w Polsce. Jednakże z perspektywy dzieci bliskość granicy nie ma tak dużego znaczenia. Chociaż przeprowadziły się tylko o 20-30 kilometrów, to ich doświadczenie nie różni się moim zdaniem zbytnio od opisywanych przez badaczy doświadczeń migracji dalszych. Co prawda bliskość granicy pozwala dzieciom na odwiedziny u dawnych znajomych (jeśli mieszkały w Polsce wystarczająco długo i zdążyły nawiązać znajomości, np. w szkole), jednak mówiąc o swojej sytuacji, opisują podobne doświadczenia co dzieci, które wyjeżdżają daleko (Strzemecka 2014, 2016; Young 2019). Rozbieżność w postrzeganiu znaczenia migracji dla dzieci przez rodziców i przez nie same skłania do poważnego traktowania głosu dzieci.

Badania nad migracjami często opierały się na niewypowiedzianym założeniu, że migrant to dorosły (Dobson 2009, s. 355, cyt. za Pustułka, Ślusarczyk, Strzemecka 2016), a dziecko traktowane jest jako „bagaż” (Orellana i in. 2001, s. 578, cyt. za Pustułka, Ślusarczyk, Strzemecka 2016). Coraz częściej jednak dostrzega się sprawczość migrujących dzieci (Hess, Shandy 2008, s. 765, 767; Ensor, Goździak 2010, cyt. za Pustułka, Ślusarczyk, Strzemecka 2016; Young 2019). Badania te, choć opisują wiele trudności, z którymi muszą mierzyć się dzieci migrantów, pokazują także, jak używają one nabieranych z czasem kompetencji kulturowych i językowych do aktywnego budowania swojej tożsamości i formułowania planów na przyszłość (Trąbka 2014, cyt. za Popyk, Pustułka, Trąbka 2019, s. 245). Podkreśla się potrzebę opisania zjawiska „dorastania transkulturowo” (De Lima, Whitehead, Punch 2012), „migracji transnarodowych" czy „transnarodowego pola społecznego" (np. Levitt 2001; Basch, Glick Schiller, Szanton Blanc 1995) z perspektywy dzieci.

$\mathrm{Z}$ moich badań wynika, że doświadczanie migracji przez dzieci na przygraniczu polsko-niemieckim różni się znacznie od tego, jak widzą je rodzice, wpisuje się natomiast w obszar najnowszych badań nad migracją dzieci. Dzieci na przygraniczu mierzą się z tymi samymi kwestiami co dzieci migrujące daleko, równocześnie 
pozostając sprawczymi aktorami wpływającymi na proces migracji i swoje doświadczenie, stale negocjującymi swoją przynależność (Pustułka, Ślusarczyk, Strzemecka 2016; Pustułka, Trąbka 2019; Young 2019). Uwzględnienie perspektywy dzieci pozwala także na krytyczne spojrzenie na klasyczne teorie pogranicza.

O dziecięcym doświadczeniu migracji pisały między innymi Paula Pustułka, Magdalena Ślusarczyk i Stella Strzemecka (2016). W tekście dotyczącym badań z polskimi dziećmi w Norwegii Strzemecka (2014) zauważa, że rodzice często idealizują sytuację swoich dzieci, podczas gdy one same doświadczają wielu dylematów i trudności. Doświadczenie moich rozmówców jest często podobne, nie musi być jednak widziane $\mathrm{w}$ jednoznacznie negatywnym świetle, chodzi przede wszystkim o fakt, że migracja, choć przygraniczna i często nie tak znacząca dla rodziców, dla dzieci jest całościowym życiowym wydarzeniem i dużą zmianą niezależnie od bliskości Polski. Są świadome swojej sytuacji, kompetencji językowych, różnic na tle narodowym (które także one same aktywnie konstruują i rekonstruują w zależności od kontekstu). Ich świadomość różnicy jest także aktywowana przez aktorów społecznych (szkołę, rodzinę, grupę rówieśniczą). Autorki skupiają się na kwestii tożsamości i przynależności i zauważają, że po pokonaniu początkowych trudności dziecięce tworzenie tożsamości jest często hybrydyczne i relatywne (Vertovec 2007, cyt. za Pustułka, Ślusarczyk, Strzemecka 2016). Prezentowane przez nie podejście do kwestii migracji dzieci jest, jak same zaznaczają (tamże, s. 1), uzupełnieniem wcześniejszych badań ukazujących, że osoby, które jako dzieci dorastały transnarodowo, mogą czerpać korzyści z form bilokowanego kapitału społecznego (Reynolds 2008, cyt. za Pustułka, Ślusarczyk, Strzemecka 2016, s. 3).

Bycie przyjętym/ą przez rówieśników/czki, jest dla dzieci migrantów/ek kluczową kwestią (Strzemecka 2016). W fazie postmigracyjnej (Muszel 2016) dzieci zwykle odczuwają oderwanie od znanych im modeli życia codziennego i stylów życia oraz utratę statusu, co prowadzi do tymczasowego poczucia utraty bezpieczeństwa i poczucia inności lub nienależenia do grupy rówieśniczej (Ni Laoire i in. 2011, s. 161). Przyswojenie języka kraju przyjmującego jest zaś kluczem do uczestnictwa w społeczności rówieśniczej i w życiu szkolnym (Strzemecka 2015, s. 94). Opowieści moich młodszych rozmówców bardzo często ujawniają początkowe trudności z wkroczeniem w nową rzeczywistość:

Ula: Nie czuję się najlepiej, bo Niemcy przezywają i kiedyś chłopiec, jak szłam po szkole, wywalił mi wszystkie rzeczy. Kiedyś chciałam się stąd wyprowadzić, bo wszyscy mnie przezywali.

Trudności często udaje im się pokonać wraz z nabraniem kompetencji językowych. O wiele trudniej jest jednak dzieciom, które przeprowadziły się do Niemiec po dziesiątym roku życia.

$\mathrm{U}$ : ja się uczę, w szkołach są takie $\mathrm{DaF}^{6}$, czyli niemiecki za drugi język. [...] U mnie Niemcy z tymi nowymi Polakami za bardzo nie rozmawiają, ale z tymi Polakami, co są już od podstawówki to bardzo często.

${ }^{6}$ Deutsch als Fremdsprache. 
Badacze migracji dzieci (Portes, Lingxin 2004; Strzemecka 2014, 2015, 2016) opisują specyficzny problem pokolenia 1,5 - dzieci urodzonych w kraju pochodzenia swoich rodziców i dorastających częściowo w państwie przyjmującym, którym o wiele trudniej jest oswoić się z nową rzeczywistością. Badania wykazują, że wejście w środowisko rówieśnicze jest dla nich równocześnie najtrudniejszym i najważniejszym wyzwaniem, a kluczowym czynnikiem pozwalającym na uczestniczenie w życiu rówieśniczym i szkolnym są kompetencje językowe. Słaba znajomość niemieckiego pogłębia poczucie obcości i stres, a także może być podłożem konfliktów między dziećmi. Doświadczenia moich rozmówców nie zawsze są jednoznacznie negatywne, jednak podkreślają oni trudności z wejściem w nową rzeczywistość, które przez rodziców są bagatelizowane.

W przypadku terenu moich badań na dynamikę relacji wpływa także duża liczba polskich dzieci. W Nadrensee dzieci jeżdżą do szkoły podstawowej w X, gdzie większość ma znajomych zarówno polskich, jak i niemieckich. Jednak po powrocie do domu spędzają czas wyłącznie wśród innych polskich dzieci. W tej wsi rodziny z dziećmi pochodzą niemal wyłącznie z Polski i większość z nich zamieszkuje bloki, które mieszczą się na końcu wsi. Towarzystwo podwórkowych zabaw i wzajemnych odwiedzin stanowią więc dzieci Polaków. Brak „integracji” wynika m.in. z izolacji przestrzennej, częstej dla migrantów, zwłaszcza na początku pobytu migracyjnego.

B.R.: A tu nie mieszkają niemieckie dzieci?

Basia: Mieszkają też, ale mało. Raczej się nie trzymamy z nimi. Wolę rozmawiać po polsku, bo po niemiecku jest trudno. Kiedyś cała klasa mnie wyśmiała, że źle powiedziałam jedno słowo po niemiecku. Ula: Ja jeszcze w ogóle tak do końca nie mówię po niemiecku.

Wielu dzieciom trudności sprawia również nauka w obcym języku. Według Michała rozmawiają po polsku, gdy tylko mogą, na przykład z nauczycielem biologii, który jest Polakiem. Dzięki temu Michał może pytać go podczas lekcji o niektóre słowa i łatwiej mu się ich nauczyć. Kiedy spytałam, z kim zadają się na co dzień, odpowiedzieli zgodnie, że bardziej z Polakami. Wyraziłam zdziwienie, mówiąc, że pewnie mówią już dobrze po niemiecku, jednak uznali, że to „za dużo powiedziane”. Spytałam więc, czy to przez język trzymają się bardziej z Polakami, i odpowiedzieli:

Kuba: Nie, z Niemcami też, ale wolimy po prostu z Polakami. Tak luźniej jest.

Michał: Jest luźniej i ja na przykład się czasami boję, że coś źle powiem po niemiecku i się ośmieszę jakby przed tymi Niemcami.

Dzieciom, które przeprowadziły się do Niemiec po dziesiątym roku życia, trudniej jest nauczyć się niemieckiego i dostosować do nowego środowiska, stąd między innymi częste wyraźne podziały w szkole na Niemców i Polaków. Kwestia kontaktów z rówieśnikami i „naturalności” dziecięcego wrastania w środowisko niemieckie nie jest tak oczywista, jak wydaje się rodzicom. Podziały na tle narodowym nie są czymś stałym, istniejącym per se, lecz są konstruowane w dynamicznym procesie zależnym od kontekstu. Dzieci i młodzież na przygraniczu są tych podziałów świadomi i sami aktywnie je tworzą. 
Kasia: Na przykład w mojej klasie jest tak, że są Niemcy, którzy mnie i moją koleżankę, którzy już tak po niemiecku dobrze rozmawiają, akceptują i im nie przeszkadza, jak rozmawiamy po polsku. Ale są też inni Polacy, którzy mówią tylko po polsku, nie wiem, nie umieją po niemiecku albo im się nie chce. No i tych tak bardzo nie lubią, no i zawsze są przeciw nich, ich. Czasami się tak trochę kłócą, ale klasa to klasa.

B.R: Na przykład o co?

K: No nie wiem, na przykład ci Niemcy do mnie mówią, i tak zawsze gadają co im się w tamtych nie podoba, i zawsze jak coś robimy i mamy o czymś rozmawiać, to mają przeciwne zdania.

Opowieści oraz interpretacje dzieci dotyczące podziałów i konfliktów na tle narodowym są szczególnie ciekawe w zestawieniu z narracją rodziców, którzy zazwyczaj idealizują i upraszczają obraz asymilacji dzieci. Interesująca była dla mnie rozmowa przeprowadzona ze świetliczanką w niemieckiej podstawówce, jej 15-letnim synem Kubą i jego kolegą Michałem - uczniami Regionale Schule w Loecknitz. Kobieta jest świadoma tego, jak ciężko jej syn przeszedł przeprowadzkę, i ma wyrzuty sumienia. Podczas rozmowy nieustannie starała się przekonać i siebie, i syna, że to doświadczenie wyjdzie mu na dobre, i że nie jest już tak źle jak było na początku. Kiedy chłopcy opowiadali o konfliktach między uczniami w szkole, mama słuchała z niedowierzaniem i starała się łagodzić obraz, który kreślili Kuba i Michał. Michał nie chciałby, żeby podziały i konflikty na tle narodowym wpływały na relacje między uczniami, zauważa jednak, że stereotypy nadal istnieją. Podczas tej rozmowy o stereotypach nastąpił ciekawy moment, w którym mama wyraziła przypuszczenie, że dzięki współżyciu stereotypy zmniejszają się i rośnie tolerancja, na co obaj chłopcy wyrazili swój sprzeciw.

Michał: Dla mnie wszystko jest okej, dopóki ktoś nie zaczyna atakować całej społeczności. Mogą mnie obrażać, co nie, ale jakby już przestaje mi się to podobać, kiedy zaczyna obrażać wszystkich Polaków, bo w Niemczech się wyrobił taki stereotyp, że Polacy tylko kradną. A tak nie jest.

Mama: Ale wydaje mi się, że on się już troszeczkę zamazuje...

Kuba: (przerywa) Mamo nie.... nie uczęszczasz...

B.R: Myślicie, że przez kontakty między wami te stereotypy się tworzą, znikają? Takie negatywne? Mama: Moim zdaniem, tak jak ja mogę powiedzieć, to one zanikają.

K: No, ale mama uczęszczasz do szkoły? Takiej większej? Nie do takiej malutkiej jak tutaj na przykład? No właśnie, to co ty możesz wiedzieć, z kim masz mamo kontakt?

Choć podobnych historii dzieci mogą przytoczyć wiele, świadczy to nie tyle o złych relacjach polsko-niemieckich w szkołach (można usłyszeć od nich również wiele opowieści o bardzo dobrych stosunkach między uczniami), lecz o tym, że z takimi podziałami dzieci spotykają się na każdym kroku i że na porządku dziennym jest poddawanie namysłowi i interpretacjom tego, kim jest Polak, a kim Niemiec.

Na proces konstruowania różnic na tle narodowym wpływ mają także nauczyciele (Bucholtz, Hall 2005). Jak piszą Pustułka i Trąbka (2019, s. 16), szkoła ma kluczowe znaczenie w procesie integracji, a pozytywny przebieg tego procesu zależy od obu stron, zarówno dzieci imigrantów, jak i członków społeczności przyjmującej reprezentowanej przede wszystkim przez nauczycieli i rówieśników. 
Na polsko-niemieckim przygraniczu narodowość i język stają się ważnym, choć nie jedynym kryterium, według którego młodzi ludzie dzielą się na grupy, budując swoje pola społeczne (Levitt 2001). Z moich obserwacji i rozmów wynika, że $\mathrm{w}$ decyzjach i strategiach tożsamościowych ważnymi elementami są przynależność do grupy i do środowiska, język i wspólnota doświadczeń. Pragnę podkreślić, że dzieci i młodzież są sprawczymi aktorami w procesie konstruowania tożsamości. Sara Young, rozmawiając z dziećmi polskich migrantów w Anglii (2019), zauważa, że ich wypowiedzi nie są opowieściami o byciu ofiarą (s. 110) i zwraca uwagę, w jaki sposób przedstawiają się jako aktywni aktorzy, kreujący swoje poczucie przynależności, tożsamość, pozycję społeczną (positioning; s. 112). Jednocześnie podkreśla, że budując swoją pozycję w kraju przyjmującym, dzieci wchłaniają także głosy ze swojego otoczenia: rodziców, nauczycieli, rówieśników. Dzieci pozycjonują się, ale także są pozycjonowane przez otoczenie. Pozycje i tożsamości są stale renegocjowane w praktykach dyskursywnych (McKinney, Norton 2008). Język stanowi ważne narzędzie budowania poczucia sprawczości i przynależności również dlatego, że dzieci zazwyczaj lepiej i szybciej niż ich rodzice uczą się nowego języka i często stają się ich tłumaczami i przewodnikami w nowym otoczeniu (Angelelli 2010, cyt. za Young 2019). Autorka przytacza opowieści o konfliktach wśród rówieśników, pokazując jednocześnie, w jaki sposób dzieci aktywnie starają się zmienić sytuację i wzmocnić swoje prawo do bycia w kraju imigracji, i nie pozwalają, by negatywne podejście, z którym czasem się spotykają, wpłynęło na ich plany na przyszłość.

Jest to wyraźnie widoczne także w przypadku moich badań. Dzieci, które od przedszkola i wczesnej podstawówki wychowują się w Niemczech, w pewnym momencie zaczynają się głębiej zastanawiać nad tym, kim są - Polakami czy Niemcami. Dorastają w rzeczywistości pełnej podziałów na to, co „niemieckie”, i to, co „polskie”, i niektóre z nich zastanawiają się, do której grupy należą. Pytają rodziców, czy są Polakami, czy Niemcami, często podejmując własne, skomplikowane wybory tożsamościowe, zależne od konkretnej sytuacji. „Niemiec” i „Polak” to dla nich dwa ekstrema na skali możliwych wyborów. Warto jednak zaznaczyć, że możliwości pozycjonowania się są ograniczone i zależne od zewnętrznych parametrów (Young 2019, s. 125). Young podkreśla, że w badaniach nad migracją dzieci należy brać pod uwagę zarówno sprawczość aktorów, jak i fakt, że nie jest ona taka sama jak dorosłych oraz że determinowana jest przez otoczenie, instytucje, państwo.

Jedna z moich rozmówczyń opisała, jak jej syn w wieku dojrzewania borykał się z tą kwestią. Na początku pobytu w Niemczech jego polska narodowość, czy po prostu odmienność, bywała powodem wyzwisk. Po pewnym czasie zaczął nalegać, by mama wyrobiła mu obywatelstwo niemieckie. Teraz, mając 18 lat, nazywa sam siebie Niemcem, jednak nie wypiera się swojego pochodzenia i zależy mu na zachowaniu znajomości języka polskiego u swoich przyszłych dzieci. Poczucie się Niemcem było dla niego istotnym elementem budowania pewności siebie w sytuacjach społecznych, jego wybory były odpowiedzią na konkretne społeczne sytuacje i interakcje. Dziś uważa się za Niemca, jednak deklaracje o chęci przekazania potomstwu języka polskiego pozwalają mu podtrzymywać również polską tożsamość. 
Jak pokazałam wyżej, dla rodziców, którzy zamieszkali po niemieckiej stronie przygranicza, jest niemal pewne, że migracja jest inwestycją w przyszłość dzieci. Zasobem, który zdobywają dzieci, jest według rodziców dwujęzyczność, ułatwiająca funkcjonowanie $\mathrm{w}$ dwóch społeczeństwach (najczęściej jednak z myślą o państwie niemieckim) i znalezienie dobrej pracy. Myśląc o sytuacji swoich dzieci przez pryzmat przyszłości, często mają uproszczony i wyidealizowany obraz ich doświadczenia mieszkania na przygraniczu. Czy jednak dla dzieci migrantów przyszłość jest kwestią pewności? W którym społeczeństwie ją widzą?

Dzieci i młodzież, z którymi rozmawiałam, miały pełną świadomość poziomu swojej znajomości niemieckiego i możliwych tego konsekwencji społecznych. Niepewność i brak swobody porozumiewania się w tym języku, a także możliwość nawiązywania kontaktów z Polakami, osłabiają relacje między polskimi i niemieckimi uczniami. Z drugiej strony, sprawne posługiwanie się niemieckim często łączy się z nawiązywaniem przyjaźni z Niemcami i ogólnym zadowoleniem ze swojej sytuacji. Niektórzy z czasem zaczynają czuć się swobodnie także w niemieckim gronie. Wraz z przekraczaniem bariery językowej nawiązują znajomości i czasem nawet nie wyobrażają już sobie powrotu do Polski. Jak piszą Ślusarczyk i Pustułka (2017), „mimo niebezpieczeństwa utraty poczucia przynależności do pewnej przestrzeni, w studiach transnarodowych przyjazd do nowego kraju oznacza równocześnie nowy początek, a także (częściową lub całkowitą) adaptację do nowego środowiska" (tamże, s. 27).

Dla wielu spośród moich młodszych rozmówców wszystko się zmienia wraz z oswojeniem nowego języka i nabraniem płynności w mówieniu. Z czasem, choć polska granica wciąż jest tak samo blisko, z punktu widzenia dzieci polska rzeczywistość coraz bardziej się oddala, innymi słowy - granice ich pola społecznego coraz bardziej rozbiegają się z granicą państwową (Levitt 2001; Levitt, Glick Schiller 2004). Wydawałoby się, że bliskość granicy z Polską jest równoznaczna z możliwością pójścia tam na studia, a rodzice wierzą, że wychowają dzieci w pełni dwujęzyczne, co zapewni im otwarte drzwi po obu stronach granicy. Z czasem zarówno rodzice, jak i dzieci orientują się, że wraz z latami przebytej edukacji niemieckiej dzieci coraz bardziej czują, że niemieckim posługują się znacznie lepiej niż polskim (zob. także Pustułka, Trąbka 2019). W końcu pragną kontynuować naukę w Niemczech, tu mają znajomych i do tego przygotowuje ich system oświatowy, a świadomość niepełnej znajomości języka polskiego sprawia, że obawiają się, iż w Polsce mogłyby sobie nie poradzić.

Syn jednej z moich rozmówczyń wybrał się raz z ojcem do Polski na kurs prawa jazdy. Kiedy wrócił do domu, zaprzysiągł, że już nigdy nie będzie nic załatwiać w Polsce, bo było to dla niego bardzo skomplikowane i czasochłonne z powodu braku znajomości odpowiedniego słownictwa. Większość młodych ludzi, z którymi rozmawiałam, planuje zostać w Niemczech lub wyjechać do innego kraju Europy Zachodniej. Niemal wszyscy planują opuścić region, który oceniają jako teren bez przyszłości 
i „zbyt wiejski”. Dla niektórych kontynuowanie życia w Niemczech jest jedynym rozwiązaniem, naturalnym biegiem wydarzeń - podążają za wyborami swoich rówieśników oraz za tym, do czego przygotowuje je system szkolnictwa. Dodatkowo coraz gorzej mówią i piszą po polsku, co utrudnia im drogę powrotu. Zdarza się także, że dzieci przejmują od rodziców przekonanie (borrowed voices, zob. Bakhtin 1986), że w Polsce czekałaby ich gorsza przyszłość. W takim wypadku, chociaż z punktu widzenia rodziców Polska jest rozpatrywana jako „możliwość, dla dzieci przeprowadzka staje się pierwszym krokiem do pełnej migracji i decyzję rodziców interpretują jako sygnał, że w Polsce nie warto lokować planów na przyszłość.

\section{WNIOSKI}

Zorientowanie rodziców na przyszłość dzieci i skupienie na nabywaniu przez nie znajomości języka niemieckiego może powodować, że nie dostrzegają oni złożoności doświadczenia migracji swoich dzieci. Bliskość granicy jest ważna, jednak w przypadku dzieci nie wpływa znacząco na ich doświadczenie integracji z nowym otoczeniem. Rodzicom bliskość granicy pozwala na zapewnienie dzieciom kapitału kulturowego i społecznego, a zarazem pozostawienie własnego projektu migracyjnego otwartym i niezrywanie więzi z krajem pochodzenia (Kaczmarczyk, Tyrowicz 2007). Podczas gdy sami w dużej mierze pozostają w Polsce, od dzieci oczekują pełniejszego zanurzenia w niemieckiej rzeczywistości, a ich przyszłość widzą raczej w Niemczech. Konieczność wkroczenia w nieznane środowisko szkolne i rówieśnicze i szybkiego przyswojenia nowego języka, a także dorastanie w środowisku wyraźnie podzielonym na Niemców i Polaków, jest często powodem zmagań, jednak z czasem (przede wszystkim wraz z osiągnięciem kompetencji językowych) dzieci migrantów oswajają się z nową rzeczywistością, a Niemcy stają im się bliższe niż Polska. Oddając głos dzieciom, można dostrzec, że ich doświadczenie należy interpretować bardziej przez pryzmat migracji transgranicznej i dorastania transnarodowo niż w kategoriach tworzącego się pogranicza. Dla nich zamieszkanie po niemieckiej stronie jest najczęściej doświadczeniem zanikania dawnych więzi.

Rodzice niekoniecznie uznają za swój obowiązek integrację z niemieckimi mieszkańcami czy całkowite dostosowanie się do niemieckiego stylu życia (ich doświadczenie "to nie imigracja”), natomiast swoje dzieci postrzegają jako zasymilowane. Idealizacja sytuacji dzieci czy wpasowywanie ich w nierealny wzór „współpracy”, czy koegzystencji może im służyć jako jeden z dowodów na to, że przeprowadzka była słuszną decyzją. Z perspektywy dzieci wygląda to inaczej: doświadczają one podziałów na tle narodowym w szkole i sąsiedztwie. Te podziały istnieją i są stale utrwalane i reprodukowane, przede wszystkim poprzez język, a same dzieci są aktywnymi, sprawczymi aktorami w tych procesach.

Przyjrzenie się z bliska doświadczeniom dorosłych i dzieci na przygraniczu pozwala zauważyć, że ich decyzje i interpretacje własnej sytuacji nie pokrywają się z wizją aktywistów i badaczy piszących o terenach przygranicznych czy „tworzących 
się pograniczach" (Buchowski 2004; Kaczmarek, Ładykowski 2015; Ładykowska, Ładykowski 2013; Ładykowski 2011, 2012, 2013). Zamieszkiwanie tego terenu jest zdaniem rodziców pragmatycznym zaspokajaniem swoich potrzeb dla nich samych, a dla ich dzieci - inwestycją w przyszłość. Ponieważ większość nastolatków planuje opuścić ten teren, a rodzice w dużej mierze żyją w Polsce, niekiedy nie postrzegając nawet swojej przeprowadzki jako migracji, trudno mówić o tworzeniu się polsko-niemieckiej wielokulturowej przestrzeni asymilacji czy integracji (Pasieka 2016; Zarycki 2011a; Halemba 2017). Przygranicze można więc postrzegać jako miejsce, którego zamieszkiwanie daje możliwość korzystania z zasobów po obu stronach granicy, jako „drzwi na świat”, miejsce gromadzenia kapitału na przyszłość lub miejsce jak każde inne, niekoniecznie zaś jako specyficzny teren współżycia i mieszania się kultur.

\section{LITERATURA}

Angelelli Cla ud i a 2010, A professional ideology in the making: Bilingual youngsters interpreting for their communities and the notion of (no) choice, TIS Translation and Interpreting Studies, American Translation and Interpreting Studies Association, t. 5, s. 94-108.

B a k h t in M. M. (1986), Speech genres and other late essays, red. C. Emerson, M. Holquist, University of Texas Press, Austin.

B alogh Péter 2013, Sleeping abroad but working at home: Cross-border residential mobility between transnationalism and (re)bordering, Human Geography, vol. 95, nr 2, s. 189-204.

B ucholtz Mary, Hall Kir a 2005, Language and identity, [w:] A. Duranti (red.), A companion to linguistic anthropology, Blackwell Publishing, Oxford.

B u chow ski M i chał 2004, Granica a uprawianie antropologii - uwagi wstępne, [w:] M. Buchowski, A. Brencz (red.), Polska - Niemcy. Pogranicze kulturowe i etniczne, Wydawnictwo Poznańskie, Wrocław-Poznań, s. 7-11.

Buchowski Michał 2011, Peryferie wynalezione, Kultura Liberalna, t.152, nr 49, http:// kultura liberalna.pl/2011/12/06/zarycki-lunden-buchowski-iwasiow-wymyslanie-granic/\#3, dostęp 02.10.2017.

De Lima Philomena, Whitehead Ann, Punch Samantha 2012, Exploring children's experiences of migration: movement and family relationships, CRFR Research Briefing, 61, https:// www.era.lib.ed.ac.uk/bitstream/1842/6555/1/briefing\%2061.pdf, dostęp 02.10.2017.

D obs on Madele in e E. 2009, Unpacking children in migration research, Children's Geographies, vol. 7, nr 3, https://doi.org/10.1080/14733280903024514, dostęp 02.10.2017.

Ensor Maris a, Goździak Elżbiet a M. 2010, Children and migration: At the crossroads of resiliency and vulnerability, Palgrave Macmillan, New York.

Glick Schiller Nina, Basch Linda, Blanc-Szanton Cristina 1995, From immigrant to transmigrant: Theorizing transnational migration, Anthropology Quarterly, vol. 68, no. 1, s. $48-63$.

Green S a r a h 2017, Lines, traces and tidemarks: Further reflections on forms of borders, [w:] O. Demetriou, R. Dimova (red.), The political materialities of borders: New theoretical direction, Manchester University Press, Manchester, s. 67-83.

Griffiths Melanie, Rogers Ali, Anderson Bridget 2013, Migration, time and temporalities. Review and prospect, COMPAS Research Resources Paper, https://www.compas.ox.ac. uk/media/RR-2013-Migration_Time_Temporalities.pdf, dostęp 02.10.2017.

Ha lemba Agnieszka 2017, Tworzenie pogranicza a życie przy granicy. Refleksje terminologiczne w świetle badań terenowych przy granicy polsko-niemieckiej, Etnografia Polska, t. 61, z. 1-2, s. 5-18. 
Hes s Juli a M., Sh and y D i a n n a 2008, Kids at the crossroads: Global childhood and the state, Anthropological Quarterly, vol. 81, nr 4, s. 765-776.

H o u t u m Hen k van 2011, The mask of the border, [w:] D. Wastl-Walter (red.), Research companion to border studies, Ashgate, Farnham, s. 49-62.

Junxi Qian, Hong Z hu, Yi Li u 2011, Investigating urban migrants' sense of place through a multi-scalar perspective, Journal of Enviromental Psychology, vol. 31, nr 2, s. 170-183.

Kaczmarczyk Pawel, Tyrowicz Joanna 2007, Migracje niepelne, Fundacja Inicjatyw Społeczno-Ekonomicznych, biuletyn nr 2.

Kaczmarek Łukasz, Ładykowski Paweł 2015, Ethnographic training in borderland: Students fieldwork, serendipities, and tight limits of Polish university system, Cargo Journal, vol. 10, $\mathrm{nr} 1-2$, s. 99-118.

Le vit t P e g g y 2001, Transnational migration: taking stock and future directions, Global Networks, vol. 1, nr 3, s. 195-216.

Levitt Peggy, Glick Schiller Nina 2004, Conceptualizing simultaneity: A transnational social field perspective on society, International Migration Review, t. 3, nr 38, s. 1002-1039.

Łada Agnieszka, Segeš Frelak Justyna (red.) 2012, Znikająca granica. Nowa polska migracja do Niemiec - perspektywa lokalna, Instytut Spraw Publicznych, Warszawa.

Ładykowska Agata, Ładykowski Paweł 2013, Anthropology of borders and frontiers, [w:] A. Lechevalier Arnaud, J. Wielgohs (red.), Borders and border regions in Europe. Changes, challenges and chances, Transcript, Bielefeld, s. 159-182.

Ła d y k ow ski Pawe 1 2011, The emerging Polish-German borderland: The past and the present, Baltic Journal of European Studies, vol. 1, nr 2, s. 167-191.

Ładykowski Paweł 2012, Zagadnienie węzłowe: czy Szczecin jest miastem pogranicznym, czy tylko leżącym przy granicy?, Przegląd Uniwersytecki, nr 230-232, s. 9-15.

Ła d y k ow ski P a weł 2013, Współczesny Szczecin - Ahistoryczna Aglomeracja Transgraniczna, Zeszyty Etnologii Wrocławskiej, t. 2, nr 19, s. 43-58.

McKin ney C., Nort o n B. (2008), Identity in language and literacy education, [w:] B. Spolsky, F.M. Hult (red.), The handbook of educational linguistics, Malden, MA: Blackwell, s. 192-205.

Ní Laoire Caitríona, Carpena-Méndez Fina, Tyrrell Naomi, White Allen 2011, Childhood and migration in Europe: Portraits of mobility, identity and belonging in contemporary Ireland, Ashgate, London.

Orellana Marjorie F., Thorne Barrie, Chee Anna, Lam Wan Shun Eva 2001, Transnational childhoods: The participation of children in processes of family migration, Social Problems, vol. 48, nr 4, s. 572-591.

Pas i eka Agnies zka 2016, Jak uratować pogranicze? O teoretycznych modach i metodologicznych pułapkach, Wielogłos, nr 2(28), s. 125-144.

Popyk Anzhela, Pustułka Paula, Trąbka Agnieszka 2019, Theorizing belonging of migrant children and youth at a meso-level, Migration Studies - Review of Polish Diaspora, $\mathrm{nr} 1$ (171), http://www.ejournals.eu/Studia-Migracyjne/, dostęp 02.10.2017.

Portes A lejandro, Lingxin $\mathrm{Ha} \mathrm{o}$ 2004, The schooling of children of immigrants: Contextual effects on the educational attainment of the second generation, [w:] Proceedings of The National Academy of Sciences, 101(33), red. M. Berenbaum, National Academy of Sciences, United States, s. 11920-11927; DOI: 10.1073/pnas.0403418101.

Powell Mary Ann, Taylor Nicola, Fitzgerald Robyn, Graham Ann, Anders o n D o n n h 2013, Ethical research involving children, Innocenti Publications UNICEF Office of Research - Innocenti, Florence.

Pustułka Paula, Ślusarczyk Magdalena, Strzemecka Stella 2016, Polish children in Norway: between national discourses of belonging and everyday experiences of life abroad, [w:] Z. Millei, R. Imre (red.), Childhood and nation. Critical cultural studies of childhood, Palgrave Macmillan, New York. 
Pustułka Paula, Trąbka Agnieszka 2019, New directions in researching migration of children and youth, Migration Studies - Review of Polish Diaspora, nr 1 (171), http://www.ejournals. eu/Studia-Migracyjne/, dostęp 02.10.2017.

Reynolds Tracey 2008, Ties that bind: Families, social capital and Caribbean second generation return migration, Sussex Centre for Migration Research Working Paper, nr 46.

Sadowski Andrzej 2004, Pogranicze jako przedmiot badań socjologicznych w warunkach integracji europejskiej, [w:] K. Krzysztofek, A. Sadowski (red.), Pogranicza i multikulturalizm $w$ warunkach Unii Europejskiej. Implikacje dla wschodniego pogranicza Polski, t. 1, Wydawnictwo Uniwersytetu w Białymstoku, Białystok.

Slany Krystyna, Ślusarczyk Magdalena, Pustułka Paula 2016, Polskie rodziny transnarodowe: dzieci, rodzice, instytucje i więzi z krajem, PAN, Kraków-Warszawa.

Sørensen N. Nyberg 2000, Notes on transnationalism to the panel of devil's advocates: transnational migration - useful approach or trendy rubbish? Referat na konferencji: 'Transnational Migration: Comparative Theory and Research Perspectives', ESRC Transnational Communities Programme, Oxford, UK.

S trze m e cka Stella 2014, The experience of growing up in a transnational context. Participatory research with Polish children in Norway, International Conference: Investing in Children. In Search for Innovative Solutions to Improve Children's Well-Being, Neglected Childhood, Łodź.

St r ze m e cka Stella 2015, Childhood and nation. Interdisciplinary engagements, Przeglad Socjologiczny, nr 64, s. 81-101.

Strzemecka Stella, Kryst y n S l an y 2016, Children's experience of growing up transnationally, [w:] K. Slany, J. Struzik (red.), Research Report. TRANSFAM. Doing family in a transnational context. Demographic choices, welfare adaptations, school integration and every-day life of Polish families living in Polish-Norwegian transnationality, Wydawnictwo UJ, Kraków, s. 31-39.

Ślusarczyk Magdalena, Pustułka Paula 2017, Transnarodowość w przestrzeni domowej polskich rodzin migracyjnych w Norwegii, Studia Humanistyczne AGH, nr 01(16), http://dx.doi. org/10.7494/human.2017.16.1.23, dostęp 02.10.2017.

Trą bka Agnieszka 2014, Being chameleon: The influence of multiple migration in childhood on identity construction, Studia Migracyjne - Przeglad Polonijny, t. 3, nr 153, s. 87-106.

Vertovec Steven 2007, Super-diversity and its implications, Ethnic and Racial Studies, vol. 30, z. 6, s. 1024-1054.

Yo ung S a r a 2019, 'I want to stay here forever': Narratives of resistance amongst Polish-born Adolescents in the UK, Migration Studies - Review of Polish Diaspora, $\mathrm{nr}$ (171), http://www.ejournals. eu/Studia-Migracyjne/, dostęp 02.10.2017.

Z a r y cki To m a s z 2011a, Peryferie czy pogranicza? Krytyczne spojrzenie na współczesne sposoby posługiwania się pojęciem „pogranicza”, [w:] B. Jałowiecki, S. Kapralski (red.), Peryferie i pogranicza. O potrzebie różnorodności, Wydawnictwo Naukowe Scholar, Warszawa, s. 33-54.

Z a r y ck i To m a s z 2011b, Czy warto być pograniczem?, blog Kultura Liberalna, nr 152(49), http:// kulturaliberalna.pl/2011/12/06/zarycki-lunden buchowskiiwasiowwymyslaniegranic/\#3, dostęp 02.10.2017.

\section{Źródła internetowe:}

http://www.nbp.pl/home.aspx?f=/publikacje/rynek_nieruchomosci/index2.html (NBP Baza cen nieruchomości mieszkaniowych BaRN. 2018), dostęp 25.06.2018. 
BOGNA RUTKOWSKA

\section{INHABITING „BORDERLAND”. \\ TRANSBORDER MIGRATION FROM POLAND TO GERMANY IN THE EXPERIENCE OF PARENTS AND CHILDREN}

Key words: migration, borderland, border, short distance migration, migration of children, bilingualism

The article is devoted to the migration of Poles from the vicinity of Szczecin to the German villages located close to the German-Polish border. The empirical material was collected during five field trips, each lasting two weeks, to a Polish-German border area. I present a specific type of migration - shortdistance cross-border migration - from the perspective of parents and children. I conducted research among Polish families who decided to move to one of the villages on the German side of the border, most often from Szczecin or the surrounding area. My research questions focused on the motivations for and experiences of short-distance migration. I present the perspective of parents in light of the phenomenon of future-oriented migration and the experience of children and youth "generation 1.5", outlining at the same time the specific context of the border area. I include the voice of children to contribute to the development of research on migration of families and to better understand social processes taking place around the Polish-German border.

Dane Autorki:

Bogna Rutkowska

Instytut Etnologii i Antropologii Kulturowej UW, Warszawa

ul. Żurawia 4, 00-503 Warszawa

E-mail: bodzia.rutkowska@gmail.com

ORCID: https://orcid.org/0000-0002-2356-6125 